\title{
GARRA DAMPAENSIS, A NEW RAY-FINNED FISH SPECIES (CYPRINIFORMES: CYPRINIDAE) FROM MIZORAM, NORTHEASTERN INDIA
}

\section{Samuel Lalronunga ${ }^{1}$, Lalnuntluanga ${ }^{2}$ \& Lalramliana $^{3}$}

1,2 Department of Environmental Science, Mizoram University, Aizawl, Mizoram 796009, India

${ }^{3}$ Department of Zoology, Pachhunga University College, Aizawl, Mizoram 796001, India

${ }^{1}$ samuellrna@gmail.com, ${ }^{2}$ tluanga_249@rediffmail.com, ${ }^{3}$ Irl_zoo@yahoo.co.in (corresponding author)

Abstract: Garra dampaensis, a new cyprinid fish species, is described from the Seling River, a tributary of the Khawthlang Tuipui (Karnaphuli River), in Mizoram, India. The species can be distinguished from all other Garra species, except G. abhoyai, G. lissorhynchus, G. nambulica, G. paralissorhynchus and G. rupecula by the presence of a distinct W-shaped black band on the caudal fin. It can be distinguished from the above mentioned five species in having scales on the breast and belly, shorter vent to anal distance, and by having fewer lateral line scales (27-29 vs. more than 29 in all other species). A key to the species of Garra in the Lissorhynchus complex is provided.

Keywords: Dampa Tiger Reserve, Karnaphuli, Khawthlang Tuipui, new species, Seling.

Abbreviations: HL - Head length; SL - Standard length; MUMF - Manipur University Museum of Fishes, Manipur, India; PUCMF - Pachhunga University College Museum of Fishes, Mizoram, India; ZSI - Zoological Survey of India, Kolkata, India.

Mizo Abstract: Garra dampaensis, nghalim chhungkaw zinga mi, nghazawngek chi thar chu Seling lui, Khawthlang Tuipui (Karnaphuli), Mizoram, India atanga hmuhchhuah a ni. He sangha chi thar hian a mei ah W ang tak thil dum in rin a nei a, chutiang inrin chu nghazawng ek chi dang, heng, G. abhoyai, G. lissorhynchus, G. nambulica, G. paralissorhynchus leh G. rupecula, te chauhin an nei ve a ni. Heng nghazawngek chi 5 tarlante nen an danglamna chu, a awm leh dulah te phuhlip a nei bik, a mawngkua leh a mawng pangparh inkar hlat zawng a tawi bik, tin, a taksa dungzui zawnga phuhlip intlar thla a tlem bik a ni (27-29 vs. 29 aia tam vek). Nghazawngek (Lissorhynchus complex) ho hriathran theihna tur pek a ni bawk.

DOI: http://dx.doi.org/10.11609/JoTT.03141.4368-77 | ZooBank: urn:Isid:zoobank.org:pub:CF728AC6-0507-452B-B753-A82FED642D48

Editor: W. Vishwanath, Manipur University, Imphal, India.

Date of publication: 26 May 2013 (online \& print)

Manuscript details: Ms \# 03141 | Received 29 March 2012 | Final received 07 May 2013 | Finally accepted 09 May 2013

Citation: Lalronunga, S., Lalnuntluanga \& Lalramliana (2013). Garra dampaensis, a new ray-finned fish species (Cypriniformes: Cyprinidae) from Mizoram, northeastern India. Journal of Threatened Taxa 5(9): 4368-4377; http://dx.doi.org/10.11609/JoTT.03141.4368-77

Copyright: (C) Lalronunga et al. 2013. Creative Commons Attribution 3.0 Unported License. JoTT allows unrestricted use of this article in any medium, reproduction and distribution by providing adequate credit to the authors and the source of publication.

Funding: The study was funded by University Grant Commission-North Eastern Regional Office and Zoram Educational Trust. SLRN is awardee of Mizoram University Research Scholars Fellowship.

Competing Interest: None.
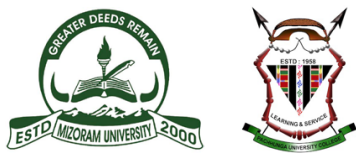

Acknowledgements: We are grateful to Director Zoological Survey of India, Kolkata for the facilities provided; Subrata Kar (ZSI) and Waikom Vishwanath (MUMF) for access to material under their care. Mizoram State Forest and Wildlife Department, especially, Mr. Laltlanhlua Zathang, Field Director, Dampa Tiger Reserve, for permission to survey. Funding for LRL from University Grant Commission-North Eastern Regional Office, Zoram Educational Trust, Mizoram, and SLRN from Mizoram University, Mizoram; facilities provided by Dr Tawnenga, Principal, Pachhunga University College, Aizawl, Mizoram are acknowledged here.

Author Contribution: SLRN - detailed examination of Garra species of Mizoram and comparison with specimens in ZSI and in other museums; LNT - supervision in identification of freshwater fish species, interpretation of the result and discusses taxonomic status; LRL - supervision in establishing new species, comparison with available literature, discusses taxonomic status, preparation of drawings and comparison with specimens in MUMF.

Author Details: SAMUEL LALRONUNGA is a research scholar, registered for PhD degree under the Department of Envinonmental Science, Mizoram University. He is working on diversity of fishes of Mizoram, northeastern India and their phylogenetic analysis. LALNUNTLUANGA is an Associate Professor in the Department of Environmental Science, Mizoram University and his field of specialization is Biodiversity. He is presently engaged in taxonomy and systematics of freshwater organisms of Mizoram. LALRAMLIANA is an Assistant Professor in the Department of Zoology, Pachhunga University College, Mizoram and his field of specialization is fish and fisheries. He is presently engaged in molecular characterization and phylogeny of freshwater fishes of Mizoram. 


\section{INTRODUCTION}

Species of the genus Garra Hamilton, 1822 are hill stream bottom dwelling cyprinids currently consisting of more than 85 described species (Chen et al. 2009), usually found in fast flowing rivers and streams adhering to submerged rocks with the help of a sucking disc present on the ventral surface of the head, just behind the mouth. The genus occurs widely from south China, Borneo and south Asia through Burma (now Myanmar), India, the Middle East, Arabian Peninsula and East Africa to West Africa (Menon 1964). During the last decade, several descriptions (Kottelat 2000; Vishwanath \& Kosygin 2000; Gopi 2001; Zhang \& Chen 2002; Zhang et al. 2002; Kullander \& Fang 2004; Vishwanath \& Joyshree 2005; Vishwanath \& Shanta 2005; Zhang 2005, 2006; Zhou et al. 2005; Li et al. 2008; Vishwanath \& Linthoingambi 2008; Chen et al. 2009; Nebeshwar et al. 2009) and revisions (Zhang et al. 2002; Zhou et al. 2005) on Garra species have been made from Asia.

The Karnaphuli River, locally known as the Khawthlang Tuipui, in Mizoram, is located between the Ganga-Brahmaputra and the Kolodyne drainages. Originating from the hills of the Mizoram-Tripura border in India, it flows along the Mizoram-Bangladesh border and then southwest through the Chittagong Hill tract and Chittagong and ultimately joins the Bay of Bengal. No previous reports have been made on any Garra species from the Karnaphuli drainage of Mizoram. Recent freshwater faunal surveys conducted in the Karnaphuli drainage of Dampa Tiger Reserve, Mizoram, India, resulted in the collection of specimens of Garra. Detailed studies and comparison of this material with congeners revealed it to belong to an unnamed species which is herein described as Garra dampaensis sp. nov.

\section{MATERIAL AND METHODS}

The specimens were preserved in $10 \%$ formalin and later on transferred to $70 \%$ alcohol. Measurements and counts follow Kullander \& Fang (2004), and that of ventral to anal fin and vent to anal fin, Menon (1964). Lateral transverse scales rows count and other additional measurements follow Nebeshwar et al. (2009). Measurements were taken point to point with digital calipers rounded to the nearest $0.1 \mathrm{~mm}$. Fin rays and numbers of scales were counted under stereo zoom microscope. For vertebral count, three paratype specimens were cleared and stained following Taylor \& van Dyke (1985). Abdominal vertebrae count include the
Weberian apparatus (assumed to contain four vertebrae). Numbers in parentheses after a meristic value indicate the frequency of that value. Specimens examined for the study are deposited in Pachhunga University College Museum of Fishes (PUCMF), Mizoram, India.

Garra dampaensis sp. nov.

(Image 1 A\&B; Image 2 A\&B)

urn:Isid:zoobank.org:act:6C1E6C12-F00B-4A9F-9E1E-55F39DA1E85E

\section{Material examined}

Holotype: PUCMF 12001, 22.vii.2011, 45.6mm SL, Seling River, a tributary of Khawthlang Tuipui (Karnaphuli River) in the vicinity of Damparengpui, Mizoram, India, $23^{\circ} 40^{\prime} 51^{\prime \prime} N$ \& $92^{\circ} 22^{\prime} 35^{\prime \prime} \mathrm{E}$, coll. Samuel Lalronunga \& Lalnuntluanga.

Paratypes: PUCMF 12002, 10 exs., 40.6-51.9 mm SL, same data as holotype; PUCMF 12003, 2 exs., 42.0-48.9 $\mathrm{mm} \mathrm{SL}$, same data as holotype (dissected for gonadal studies); PUCMF 12004, 3 exs., 36.5-41.4 mm SL, same data as holotype (dissected and preserved in glycerin with thymol for bone study).

\section{Diagnosis}

A small species of Garra with the following combination of characters: no transverse groove and proboscis on the snout; tip of dorsal fin falcate; long axillary scale present at the base of pelvic fin, reaching the base of last pelvic fin ray; 27-29 lateral-line scales, 10-11 regularly arranged predorsal scales; W-shaped black band across the middle of caudal fin and presence of scales on the breast and belly. Additional characters useful for diagnosing this species are outlined in the discussion.

\section{Description}

Biometric data are given in Table 1. Head depressed; body small, compressed and elongate. Dorsal profile gently rising from tip of snout to origin of dorsal fin then sloping gently towards caudal peduncle, body depth greatest at dorsal fin base. Ventral surface flattened from head to anal fin base. Eye ovoid, moderately large, not visible from ventral view, located in middle or slightly posterior of head length. Snout rounded without transverse groove, minute tubercles clustered (6-9) at anterior base of rostral barbels and sparsely extending on tip of snout, rostral lobe short. Head wider than deep.

Anterior barbel short, not reaching margin of rostral cap. Rostral cap connected with lower lip at corners of mouth. Upper jaw entirely covered by rostral cap. No 

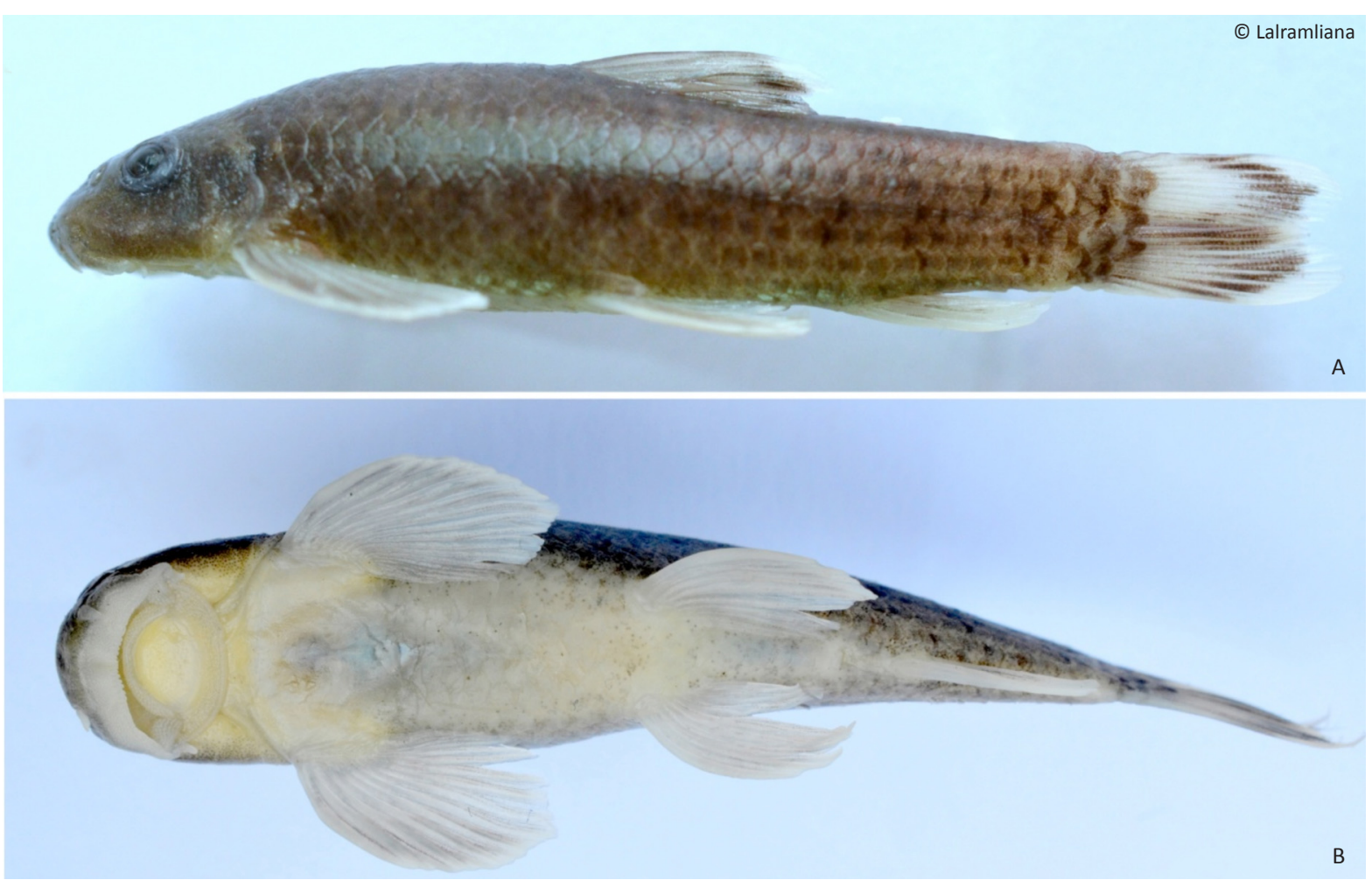

Image 1. Holotype of Garra dampaensis sp. nov. (PUCMF 11012), 46.5mm SL (A) Lateral and (B) Ventral view.
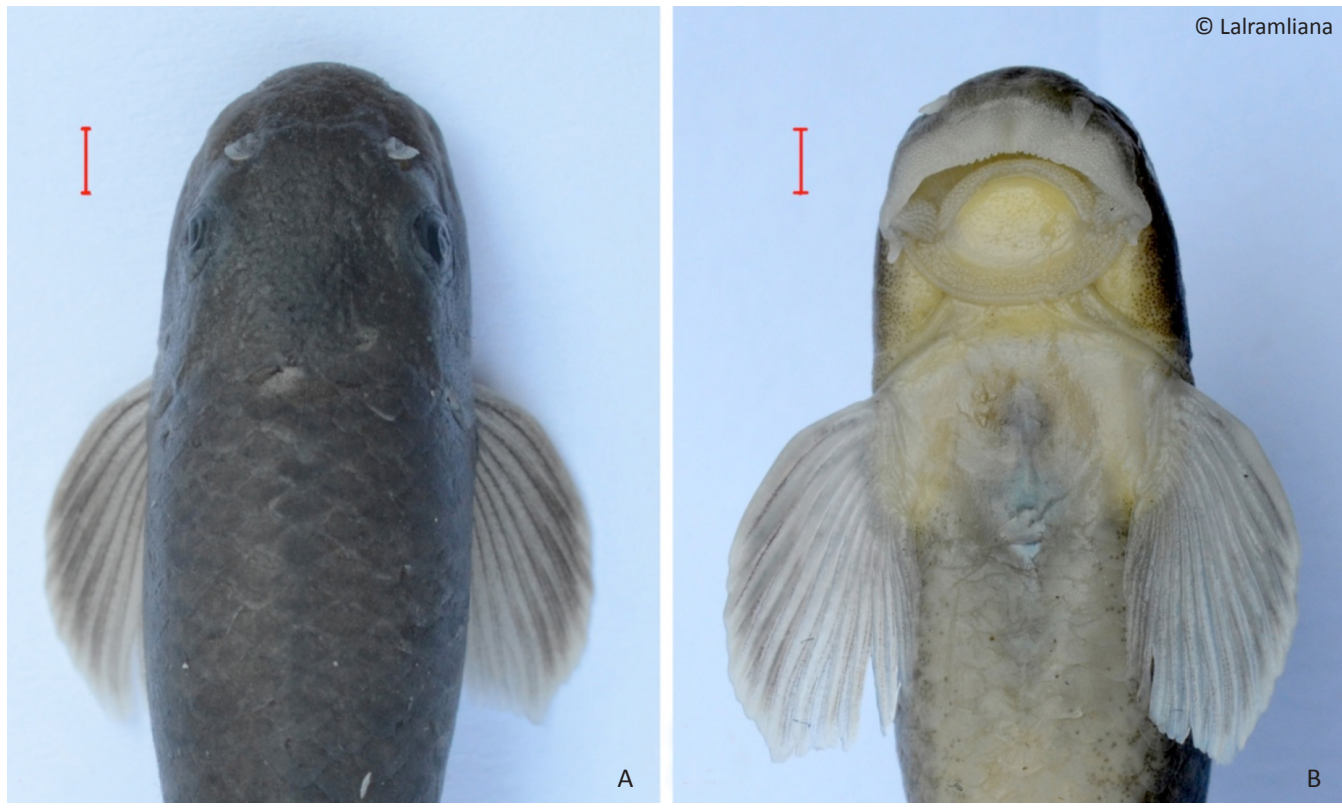

Image 2. Holotype of Garra dampaensis sp. nov. (PUCMF 11012), 46.5mm SL Head in (A) Lateral and (B) Ventral view. Scale $=2 \mathrm{~mm}$

papilliferous tissue on upper jaw. Antero-lateral fold conspicous between upper and lower lip at corner of mouth, not extending mediad between exposed lower jaw and lower lip. Lower lip thick and modified into sucking disc. Disc elliptical, wider than long; anterior margin modified to form a transverse skin fold covered by numerous tiny papillae, anteriorly separated from lower jaw by a deep groove running along lower jaw and posteriorly bordered in a deep groove with a central pad. Central pad wider than long, lateral and posterior margin 
Table 1. Biometric data for Garra dampaensis sp. nov. ( $n=16)$. All ratios expressed as percent of $\mathrm{SL}, \mathrm{HL}$, or ventral-anal length.

\begin{tabular}{|c|c|c|c|}
\hline & $\begin{array}{c}\text { Holotype } \\
\text { PUCMF12001 }\end{array}$ & $\begin{array}{l}\text { Mean } \pm S d \\
\text { Holotype } \\
\text { included }\end{array}$ & RANGE \\
\hline $\begin{array}{l}\text { Standard Length (SL) (in } \\
\mathrm{mm} \text { ) }\end{array}$ & 46.5 & & $36.5-51.9$ \\
\hline \multicolumn{4}{|l|}{ In \% SL } \\
\hline Body depth & 21.7 & $21.6 \pm 0.8$ & $20.1-22.7$ \\
\hline Head length & 27.3 & $27.4 \pm 0.6$ & $26.6-28.7$ \\
\hline Head height at eye & 13.2 & $13.5 \pm 0.3$ & $13.1-13.9$ \\
\hline Head height at occiput & 15.0 & $15.5 \pm 0.3$ & $15.0-16.0$ \\
\hline Head width at opercle & 21.3 & $20.9 \pm 0.4$ & $20.0-21.4$ \\
\hline Head width at nare & 17.7 & $17.3 \pm 0.5$ & $16.2-18.1$ \\
\hline Body width at dorsal & 17.8 & $17.3 \pm 0.5$ & $16.5-18.1$ \\
\hline Body width at anal & 10.5 & $9.6 \pm 0.6$ & $8.8-10.5$ \\
\hline Caudal peduncle length & 18.2 & $16.5 \pm 0.9$ & $15.6-18.2$ \\
\hline Caudal peduncle height & 13.4 & $13.5 \pm 0.4$ & $12.7-14.2$ \\
\hline Dorsal fin length & 25.3 & $24.7 \pm 0.9$ & $22.8-26.5$ \\
\hline Dorsal fin base length & 13.0 & $13.2 \pm 0.8$ & $12.3-14.7$ \\
\hline Pectoral fin length & 26.2 & $25.3 \pm 1.4$ & $22.9-27.1$ \\
\hline Pelvic fin length & 22.3 & $21.9 \pm 0.8$ & $20.6-23.2$ \\
\hline Anal fin length & 20.2 & $19.8 \pm 0.8$ & $18.5-21.0$ \\
\hline Anal fin base length & 8.4 & $7.8 \pm 0.4$ & $7.0-8.4$ \\
\hline $\begin{array}{l}\text { Upper caudal fin lobe } \\
\text { length }\end{array}$ & 23.8 & $25.8 \pm 1.6$ & $22.7-28.3$ \\
\hline $\begin{array}{l}\text { Lower caudal fin lobe } \\
\text { length }\end{array}$ & 24.2 & $26.3 \pm 1.5$ & $24.1-28.5$ \\
\hline $\begin{array}{l}\text { Median caudal fin rays } \\
\text { length }\end{array}$ & 20.0 & $21.1 \pm 1.4$ & $18.1-22.6$ \\
\hline Pre-anal length & 75.1 & $77.0 \pm 1.4$ & $75.1-79$ \\
\hline Pre-anus length & 71.9 & $72.7 \pm 1.2$ & $70.6-74.4$ \\
\hline Pre-ventral length & 52.9 & $53.5 \pm 1.3$ & $51.5-56.0$ \\
\hline Pre-dorsal length & 53.3 & $53.2 \pm 0.9$ & $51.5-54.7$ \\
\hline Pre-pectoral length & 22.8 & $23.4 \pm 0.9$ & $21.6-25.2$ \\
\hline \multicolumn{4}{|l|}{ In \% Ventral to anal fin } \\
\hline Vent to anal fin & 17.6 & $17.9 \pm 1.1$ & $15.9-19.6$ \\
\hline \multicolumn{4}{|l|}{ In \% HL } \\
\hline Snout length & 52.8 & $51.5 \pm 1.5$ & $48.7-54.4$ \\
\hline Eye diameter & 20.0 & $21.0 \pm 1.3$ & $18.5-22.8$ \\
\hline Inter-orbital space & 47.9 & $48.6 \pm 1.3$ & $45.9-50.3$ \\
\hline Disc length & 35.9 & $35.7 \pm 0.9$ & $34.2-37.2$ \\
\hline Disc width & 54.7 & $53.6 \pm 2.3$ & $49.0-57.9$ \\
\hline Callous pad length & 24.5 & $23.6 \pm 1.3$ & $21.4-26.6$ \\
\hline Callous pad width & 37.2 & $34.9 \pm 1.9$ & $31.9-37.6$ \\
\hline
\end{tabular}

surrounding central pad papillated, posteriormost margin almost reaching vertical to posterior margin of eye.
Dorsal fin withii,6(16) rays, falcate with sub-acuminate tip, first branched ray longest; origin closer to snout tip than caudal fin base, origin anterior to pelvic fin origin and over $10^{\text {th }}$ lateral line scales; posterior margin slightly concave. Pectoral fin sub-acuminate with i,12 (16) rays (two to three small unbranched rays posterior to the last branched ray not counted), fourth and fifth branched ray longest, adpressed fin tip reaching beyond half the distance between pectoral fin origin and pelvic fin origin or reached $9^{\text {th }}$ lateral line scale. Pelvic fin subacuminate, with i,6 (16) rays (one small unbranched ray posterior to the last branched ray not counted), second branched ray longest, adpressed fin tip reaching beyond vent but not reaching base of anal fin, axillary scale present at base of pelvic fin, reaching base of last pelvic fin ray. Vent closer to anal fin base than base of last pelvic fin ray. Anal fin sub-acuminate, with $\mathrm{ii}$ 4(16) rays, first branched ray longest, adpressed fin tip almost reaching base of caudal fin. Caudal fin deeply emarginated, lobe tips blunt, principle caudal rays $10+9(16), 10^{\text {th }}$ ray shortest, upper lobe slightly shorter than lower.

Lateral line complete and obvious; scales 27(3), 28(8) or 29(5); transverse scale rows above lateral line $3 \frac{1}{2}$ (14) or $4 \frac{1}{2}$ (2); below lateral line from ventral fin origin $3(13)$ or $4(3)$; from anal fin origin $3 \frac{1}{2}(10)$ or $4 \frac{1}{2}$ (6). Circumpeduncular scale rows 16(16). Predorsal scales $10(10)$ or $11(6)$ and arranged regularly. Belly and breast scaled; breast scales in between the pectoral fin base deeply embedded. Gill rakers 12(3).

Vertebrae: 30 ( $4+15$ abdominal +11 caudal) (2) or 31 (4 + 16 abdominal + 11 caudal) (1).

Colouration: In 70\% alcohol: dorsum, sides and head dark grey. Ventral side of head, chest, and abdomen whitish. Black spot immediately at the upper angle of gill opening. Each scale formed by blackish spot at center, more conspicuous at the posterior half. Anal, pelvic and pectoral fins whitish, pectoral fin with a black streak on each interradial membrane. Dorsal fin greyish with submarginal black band. Caudal fin grayish with distinct W-shaped black band.

Notes on biology: A dissected paratype $42.0 \mathrm{~mm} \mathrm{SL}$ is a female with ripe ovulae.

\section{Etymology}

The species is named after Dampa Tiger Reserve, Mizoram

\section{Distribution and habitat}

Known only from Seling River, inside Dampa Tiger Reserve, a tributary of Khawthlang Tuipui (Karnaphuli drainage) Mizoram, India (Fig. 1). Garra dampaensis 


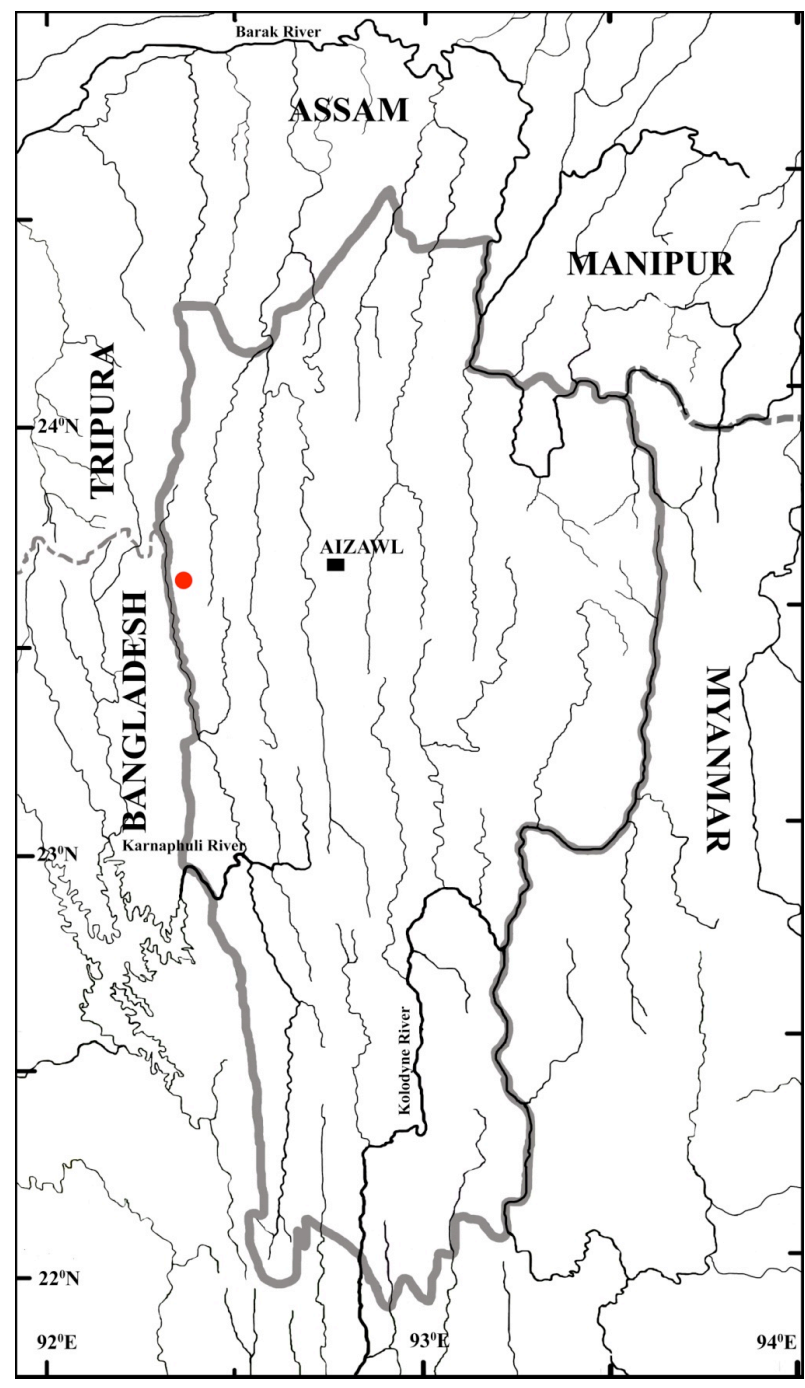

Figure 1. Map of Mizoram, India showing collection localities of (•) Garra dampaensis sp. nov. A symbol may represent more than one locality.

has been collected from clear, shallow, moderately fastflowing streams with a predominantly rocky bottom. It is found associated with Devario aequipinnatus, Garra cf. annandalei and Schistura spp.

\section{DISCUSSION}

Karmakar \& Das (2007) and Kar \& Sen (2007) reported eight species of Garra from Mizoram, namely Garra annandalei Hora, G. gotyla gotyla Gray, G. gravelyi Annandale, G. kempi Hora, G. lamta Hamilton, G. lissorhynchus McClelland, G. naganensis Hora, and G. notata Blyth from Barak drainage (Brahmaputra basin), and again $G$. annandalei, G. gotyla gotyla along with $G$. lamta and G. naganensis to occur in the Mat River (a tributary of Kolodyne) and Kolodyne River, however, the identity of some of these species needs confirmation.

From Manipur, the neighboring state of Mizoram, India, the following species has been described, namely Garra abhoyai and G. naganensis (Hora, 1921), G. manipurensis (Vishwanath \& Sarojnalini, 1988), G. litanensis (Vishwanath, 1993), G. paralissorhynchus (Kosygin \& Vishwanath, 1998), G. compressus (Vishwanath \& Shanta, 1998), G. elongata (Vishwanath \& Kosygin, 2000) and G. nambulica (Vishwanath \& Joyshree, 2005). Further, the occurrence of $G$. lissorhynchus, G. rupecula McClelland, G. kempi Hora, G. nasuta McClelland, G. gravelyi and G. gotyla has been reported from Manipur (Vishwanath 1993). Garra abhoyai has been treated as a junior synonym of G. rupecula (Menon, 1964), however, Vishwanath \& Linthoingambi (2008) resurrected the species and ruled out the occurrence of G. rupecula in the Chindwin basin of Manipur.

Among the aforementioned species, Garra gotyla gotyla, G. lamta, G. litanensis, G. elongata, G. arupi and $G$. nasuta are closely related to each other in having a transverse groove and also a weak to well developed proboscis on the snout. Garra dampaensis clearly differs from any of them in having a snout without a transverse groove.

Garra dampaensis shares similar characters with G. annandalei, G. naganensis, G. notata, G. kempi, $G$. compressus and $G$. manipurensis in having a snout without a transverse groove and a proboscis, and in certain body proportions and counts. However, it can be easily distinguished from them by the presence (vs. absence) of a distinct $W$-shaped black band on the caudal fin.

McClelland (1839) described Gonorhynchus rupeculus from the Mishmi Hills, Arunachal Pradesh, India (Brahmaputra basin). The description is very brief and he did not mention the presence or absence of wavy or W-shaped black bar across the caudal fin, but reported 35 scales along the lateral line and nine rows of scales on either side between the dorsal and ventral fins; a snout smooth and broad; a row of open pores extending round the snout between the nostrils, and another row between the eyes, besides other characters. Gunther (1868) and Day (1878), without any comments, considered it as a synonym of Discognathus lamta Hamilton (now Garra lamta), a species with a deep transverse groove separating the snout tip and no wavy or W-shaped black bar across the caudal fin. Similarly, Platycara lissorhynchus was described by McClelland (1842) from Kasyah Mountains, Assam (Bhrahmaputra basin) to possess a head, flat below, arched and thick above; a 
disc behind the mouth; a snout smooth and rounded; and scales large. The two species were recognized and redescribed as Garra rupecula (as G. rupeculus by Hora 1921) and G. lissorhynchus respectively by Hora (1921) and Menon (1964), mentioning the absence of scales on the ventral side (chest and abdomen), presence of wavy or W-shaped black bar across the caudal fin in both the species and lateral line scales as 32-34 for $G$. rupecula and 32-35 for G. lissorhynchus. However, the descriptions on G. rupecula by Hora (1921) and Menon (1964) are based on specimens collected from Manipur valley, which belong to Chindwin drainage (Nebeshwar et al. 2009). Since the distribution of G. rupecula in the Chindwin basin is already ruled out (Vishwanath \& Linthoingambi 2008; Nebeshwar et al. 2009), it can be considered that their examined specimens are totally different species (probably a mixture of small specimens of Garra nambulica and G. paralissorhynchus, as mentioned by Vishwanath \& Linthoingambi 2008). It is thus obvious that the description of $G$. rupecula available is the only brief statement by McClelland (1839), and we therefore consider that a thorough revision is essential to depict the detail characters of the species.

Menon (1964) grouped Garra species having a dark streak near the free margin of the dorsal fin, W-shaped band on the caudal fin and naked breast and belly in the Lissorhynchus complex. Species which can be put under this group are G. lissorhynchus, G. rupecula, G. abhoyai, $G$. paralissorhynchus and $G$. nambulica. The species under description shares similar characters with them in having a dark streak near the free margin of dorsal fin and distinct W-shaped black band on the caudal fin. However, it can be easily distinguished from them in having scales on breast and belly (vs. absent in all) (see Table 2 for comparison). It further differs from $G$. lissorhynchus in having fewer lateral line scales (27-29 vs. 34-35) and fewer predorsal scales (10-11 vs. 14-15); from G. rupecula, as mentioned by McClelland (1839), in having fewer lateral line scales (27-29 vs. 35); from G. abhoyai in having deeper body (20.1-22.7 \% SL vs. 17.6-18.7), longer head (26.6-28.7\% SL vs. 22.0-23.5), longer dorsal fin (22.8-26.5 \% SL vs. 11.7-14.8), longer pectoral fin (22.9-27.1\% SL vs. 19.7-22.0), longer pelvic fin (20.6-23.2 \% SL vs. 16.5-18.2) and regularly arranged 10-11 predorsal scales (vs. appears to be naked due to thick mucous cover); from G. paralissorhynchus in having more gill rakers (12 vs. 6 ) and shorter vent to anal distance (15.9-19.6\% ventral-anal distance vs. 25.030.8); and from $G$. nambulica in having fewer lateral line scales (27-29 vs. 34-35), fewer predorsal scales (10-11 vs. $16-29)$, longer head (26.6 -28.7 \% SL vs. 20.7-25.1), longer dorsal fin (22.8-26.5 \% SL vs. 17.4-20.4), longer pectoral fin (22.9-27.1\% SL vs. 17.0-20.8), longer pelvic fin (20.6 - $23.2 \%$ SL vs. 15.2-17.9), longer snout (48.754.4\% HL vs. 29.1-33.0) and shorter vent to anal distance (15.9-19.6\% ventral-anal distance vs. 33.6-43.6).

Kullander \& Fang (2004) described seven species of Garra viz. G. propulvinus, G. vittatula, G. rakhinica, $G$. flavatra and $G$. nigricollis from the western slope of the Rakhine Yoma, while G. spilota and G. poecilura from the eastern slope of the Irrawaddy drainage. Garra dampaensis sp. nov. differs from all the species described from Rakhine Yoma and Irrawaddy drainage, except G. propulvinus and G. rakhinica, in absence (vs. presence) of a narrow band of papilliferous tissue along the upper jaw, and a short pleated papilliferous fold that extends mediad from the corner of the mouth between the exposed lower jaw and the lower lip. Further, G. dampaensis differs from $G$. propulvinus in having fewer vertebrae (26-27 vs. 28-29), fewer unbranched dorsal fin (2 vs. 3), fewer lateral line scales (27-29 vs. 31), longer head (26.6-28.7\% SL vs. 23.4-25.3), shallower body depth (20.1-22.7\% SL vs. 26.6-28.9), shorter dorsal fin (22.8- 26.5\% SL vs. 31.3-34.2) and shorter anal fin (18.5-21.0\% SL vs. 23.3-27.5); from G. rakhinica in having fewer unbranched dorsal fin (2 vs. 3), shallower body (20.1-22.7 \% SL vs. 27.2-28.8), shorter dorsal fin (22.8-26.5\% SL vs. 28.7-32.3), shorter pectoral fin (22.9-27.1\% SL vs. 28.6-30.8), shorter anal fin (18.521.0 \% SL vs. 23.3-24.7) and also absence (vs. present) of horizontal black stripes from base of anterior barbel to preopercle.

Rahman (2005) listed Garra annandalei and Garra gotyla gotyla, both from the Brahmaputra basin in Bangladesh. However, as noted above, both are readily distinguished from the new species.

\section{Comparative material}

Garra abhoyai: MUMF 6296-6305, 17.i.2003, 10 exs., 50.6-55.7 mm SL, Iril River, Phungdhar, Manipur, K. Nebeshwar, M. Shantakumar \& I. Linthoingambi.

Garra annandalei: MUMF 5088-5090, 20.iii.2000, 3 exs., 52.1-68.2 mm SL, Tuivai River, Churachandpur, Shanta Devi.

Garra compressus: MUMF 2316 (holotype), 17.iii.1998, 69.6mm SL, MUMF 2314-2315, paratype, 2 exs., 80.7-84.2 mm SL, Wanze Stream at Khamson, Ukhrul District, Manipur (Chindwin basin), L. Kosygin.

Garra elongata: MUMF 2311 (holotype), 12.xi.1997, 87.7mm SL; MUMF 2308-2310, paratypes, 3 exs., 74.1$82.8 \mathrm{~mm}$ SL, a small stream near Tolloi, Ukhrul District, Manipur (Chindwin Basin), L. Kosygin. 
Garra gotyla gotyla: ZSI 9955/1, 1 ex., 102.2mm SL, Kangra Hill Stream, Punjab.

Garra gravelyi: MUMF 4173, 17.viii.1999, 1 ex., 74.6mm SL, Leimatak River, Manipur, K. Nebeshwar.

Garra kempi: Data from Zhang \& Chen (2002).

Garra lamta: Data from Menon (1964).

Garra lissorhynchus: MUMF 4163-4166, 02.ix.2000, 4 exs., 69.2-87.5 mm SL, lyei River at Noney, Tamenglong District (Brahmaputra Basin), K. Nebeshwar.

Garra litanensis: MUMF-68/1 (holotype), 16.iii.1986, $90.1 \mathrm{~mm}$ SL, Litan Stream, Litan, Manipur, W. Vishwanath.

Garra naganensis: MUMF 4156-4159, 20.xi.1999, 4 exs., 78.2-103.4 mm SL, Barak River, Vanchengphai Village, Tamenglong District, Manipur (Brahmaputra basin); K. Nebeshwar.

G. nambulica: MUMF 8004-8008, 5 exs., 41.5-58.7 $\mathrm{mm} \mathrm{SL}$, Conchak lok, stream of Nambul River, Manipur (Chindwin basin).

Garra nasuta: MUMF 4079, 10.xi.1999, 3 exs., 115.2118.7 mm SL, Barak River at Khunphung, Manipur, K. Nebeshwar

Garra notata: Data from Menon (1964).

Garra paralissorhynchus: MUMF 5054 (holotype), 25.vii.2000, 64.2mm SL, Khuga River, Churchanpur District, Manipur (Chindwin Basin); L. Shanta Devi. Additional data from Vishwanath \& Shanta (2005).

Garra propulvinus, G. vittatula, G. rakhinica, G.flavatra, G. nigricollis, G. spilota, and G. poecilura:
Data from Kullander \& Fang (2004). Garra rupecula: Data from Mc Clelland (1839)

\section{REFERENCES}

Chen, Z., S. Zhao \& J. Yang (2009). A new species of the genus Garra from Nujiang River Basin, Yunnan, China (Teleostei: Cyprinidae). Zoological Research 30(4): 438-444; http://dx.doi.org/10.3724/ SP.J.1141.2009.04438

Day, F. (1878). The Fishes of India: Being a Natural History of The Fishes Known to Inhabit The Seas and Freshwaters of India, Burma and Ceylon. Berdnard Quaritch, London, i-xx+778pp.

Gopi, K.C. (2001). Garra periyarensis, a new cyprinid fish from Periyar Tiger Reserve, Kerala, India. Journal of the Bombay Natural Historical Society 98: 80-83.

Günther, A. (1868). Catalogue of The Fishes in The British Museum. Department of Zoology, British Museum (Natural History), London 7: i-xx+512pp.

Hora, S.L. (1921). Indian cyprinoid fishes belonging to the genus Garra, with notes on related species from other countries. Records of Indian Museum 22: 633-687.

Kar, D. \& N. Sen (2007). Systematic list and distribution of fishes in Mizoram, Tripura and Barak drainage of northeastern India. Zoos' Print Journal 22(3): 2599-2607; http://dx.doi.org/10.11609/JoTT. ZPJ.1571a.2599-607

Karmakar, A.K. \& A. Das (2007). Fishes. In: Fauna of Mizoram, State Fauna Series 14, Part 1. Zoological Survey of India, Kolkata, 691pp.

Kottelat, M. (2000). Diagnoses of a new genus and 64 new species of fishes from Laos (Teleostei: Cyprinidae, Balitoridae, Bagridae, Syngnathidae, Chaudhuriidae and Tetraodontidae). Journal of South Asian Natural History 5: 37-82.

Kullander, S.O. \& F. Fang (2004). Seven new species of Garra (Cyprinidae: Cyprininae) from the Rakhine Yoma, southern Myanmar. Ichthyological Exploration of Freshwaters 15: 257-278.

Li, F., W. Zhou \& Q. Fu (2008). Garra findolabium, a new species of cyprinid fish (Teleostei: Cypriniformes) from the Red River drainage

Table 2. Comparison of Garra dampaensis sp. nov. with related species.

\begin{tabular}{|c|c|c|c|c|c|c|}
\hline & Gdam & Gliss & Grupe & Gabho & Gpara & Gnamb \\
\hline \multicolumn{7}{|l|}{ In \% SL } \\
\hline Body depth & $20.1-22.7$ & $18.2-20.8$ & - & $17.6-18.7$ & $19.3-25.7$ & $16.4-20.5$ \\
\hline Head length & $26.6-28.7$ & $23.1-23.6$ & - & $22.0-23.5$ & $20.0-26.8$ & $20.7-25.1$ \\
\hline Dorsal fin length & $22.8-26.5$ & $18.5-19.4$ & - & $11.7-14.8$ & 19.9 & $17.4-20.4$ \\
\hline Pectoral fin length & $22.9-27.1$ & $20.4-22.2$ & - & $19.7-22.0$ & 21.7 & $17.0-20.8$ \\
\hline \multicolumn{7}{|l|}{ In \% ventral-anal } \\
\hline Vent- anal distance & 15.9-19.6 & $24.6-26.9$ & - & $37.6-46.0$ & $25.0-30.8$ & $34.0-43.4$ \\
\hline \multicolumn{7}{|l|}{ In\% HL } \\
\hline Snout length & $48.7-54.4$ & $45.8-53.5$ & - & $44.0-48.0$ & $46.8-57.7$ & $29.1-33.0$ \\
\hline \multicolumn{7}{|l|}{ Meristic count } \\
\hline Lateral line scales & $27-29$ & $34-35$ & 35 & $30-33$ & $30-31$ & $34-35$ \\
\hline Predorsal scales & $10-11$ & 14-15 & - & - & $11-12$ & $16-29$ \\
\hline Circumpeduncular scales & 16 & 16 & 16 & 16 & 16 & 16 \\
\hline Gill rakers & 12 & 12 & - & - & 6 & 10 \\
\hline Scales on chest & present & absent & absent & absent & absent & absent \\
\hline
\end{tabular}

Gdam - Garra dampaensis sp. nov.; Gliss - G. lissorhynchus; Grupe - G. rupecula; Gabho - G. abhoyai; Gpara - G. paralissorhynchus; Gnamb - G. nambulica 


\section{Keys to the species of Garra in the Lissorhynchus complex}

1. Breast and belly scaled; Lateral line with $27-29$ scales

G. dampaensis sp. nov Breast and belly naked; Lateral line with more than 29 scales

2. Lateral line with $30-31$ scales; $11-12$ predorsal scales

G. paralissorhynchus Lateral line with or more than 30 scales

3. Lateral line with 30-33; predorsal region covered by thick mucous, scales irregularly arranged G. nambulica

4. Lateral line with 34-35 scales; 14-15 predorsal scales G. lissorhynchus Row of open pores on inter-orbital, and on inter-narial region G. rupecula

in Yunnan, China. Zootaxa 1743: 62-68.

McClelland, J. (1839). Indian Cyprinidae. Asiatic Researches 19(2): 217-471.

McClelland, J. (1842). On the fresh-water fishes collected by William Griffith, Esq., F. L. S. Madras Medical Service, during his travels under the orders of the Supreme Government of India, from 1835 to 1842. Calcutta Journal of Natural History 2(8): 560-589.

Menon, A.G.K. (1964). Monograph of the cyprinid fishes of the genus Garra, Hamilton. Memoirs of the Indian Museum 14(4): 173-260.

Nebeshwar, K., W. Vishwanath \& D.N. Das (2009). Garra arupi, a new cyprinid fish species (Cypriniformes: Cyprinidae) from upper Brahmaputra basin in Arunachal Pradesh, India. Journal of Threatened Taxa 1(4): 197-202; http://dx.doi.org/10.11609/JoTT. o1842.197-202

Rahman, A. K. A. (2005). Freshwater Fishes of Bangladesh (Second edition). The Zoological Society of Bangladesh, Department of Zoology, University of Dhaka, Dhaka, 394pp.

Taylor, W.R. \& G.G. van Dyke (1985). Revised procedures for staining and clearing small fishes and other vertebrates for bone and cartilage study. Cybium 9: 107-119.

Vishwanath, W. \& H. Joyshree (2005). A new species of the genus Garra Hamilton-Buchanan (Teleostei: Cyprinidae) from Manipur, India. Zoos' Print Journal 20(4): 1832-1834; http://dx.doi.org/10.11609/ JoTT.ZPJ.1228.1832-4
Vishwanath, W. \& I. Linthoingambi (2008). Redescription of Garra abhoyai Hora (Teleostei: Cyprinidae: Garrinae) with a note on Garra rupecula from Manipur, India. Journal of the Bombay Natural History Society 105(1): 101-104.

Vishwanath, W. \& L. Kosygin (2000). Garra elongata, a new species of the subfamily Garrinae from Manipur, India (Cyprinidae, Cypriniformes). Journal of the Bombay Natural Historical Society 97: 408-414.

Vishwanath, W. \& K. Shanta (2005). A new species of Garra HamiltonBuchanan (Cypriniformes: Cyprinidae) from Manipur, India. Journal of the Bombay Natural Historical Society 102(1): 86-88.

Zhang, E. (2005). Garra bispinosa, a new species of cyprinid fish (Teleostei: Cypriniformes) from Yunnan, southwest China. Raffles Bulletin of Zoology (Supplement) 13: 9-15.

Zhang, E. \& Y.Y. Chen (2002). Garra tengchongensis, a new cyprinid species from the upper Irrawaddy River basin in Yunnan, China (Pisces: Teleostei). Raffles Bulletin of Zoology 50: 459-464.

Zhang, E., S.P. He \& Y.Y. Chen (2002). Revision of the Cyprinid genus Placocheilus Wu, 1977 in China, with description of a new species from Yunnan. Hydrobiologia 487: 207-217.

Zhou, W., X.F. Pan \& M. Kottelat (2005). Species of Garra and Discogobio (Teleostei: Cyprinidae) in Yuanjiang (Upper Red River) drainage of Yunnan Province, China with description of a new species. Zoological Studies 44: 445-453. 


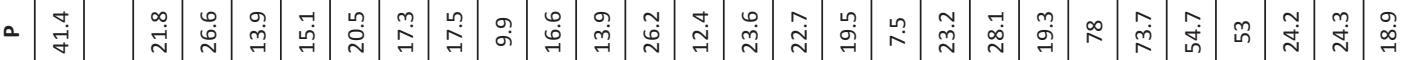
s。

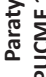

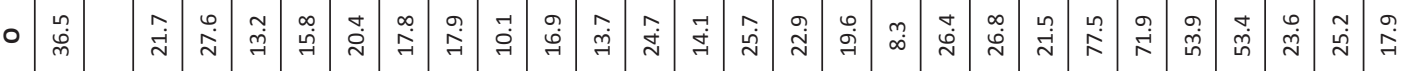

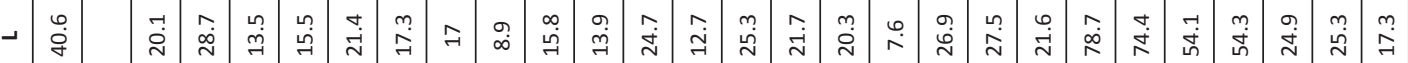

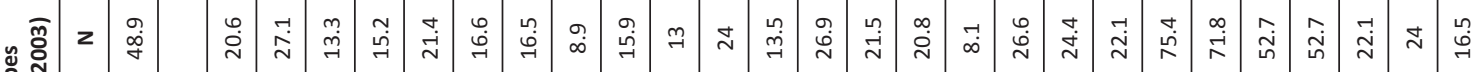

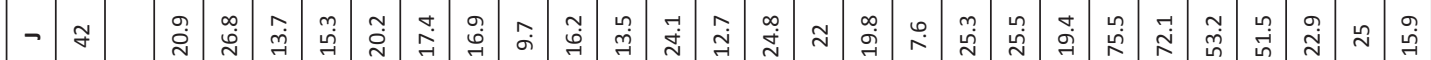

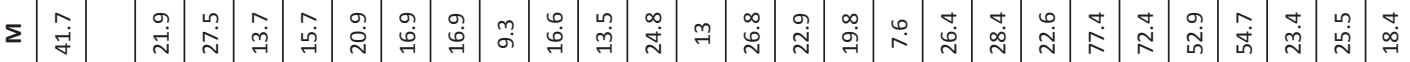

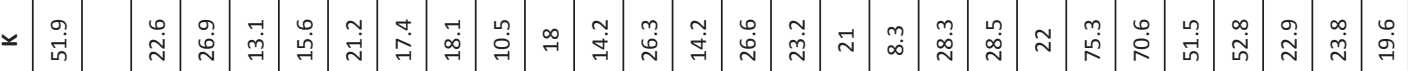

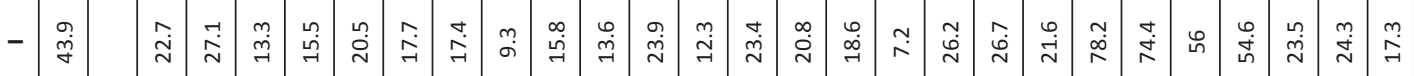

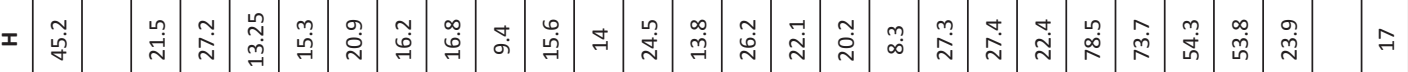

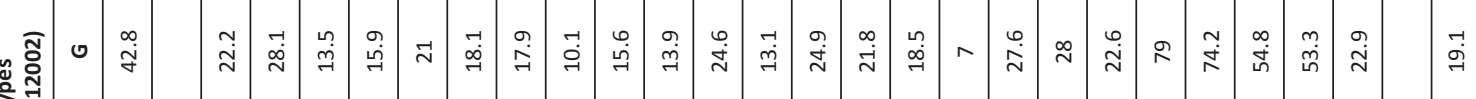

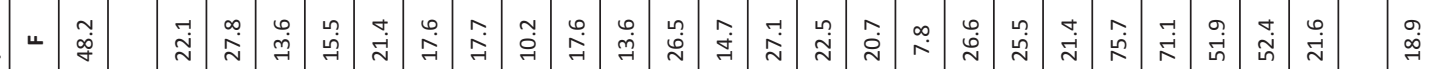

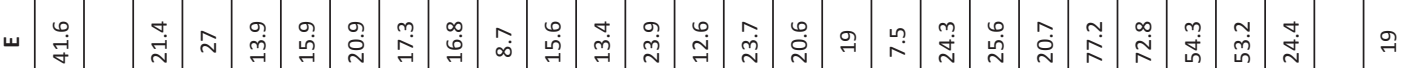

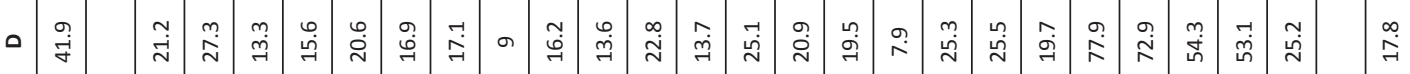

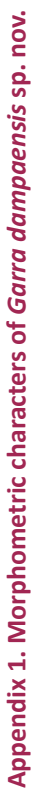

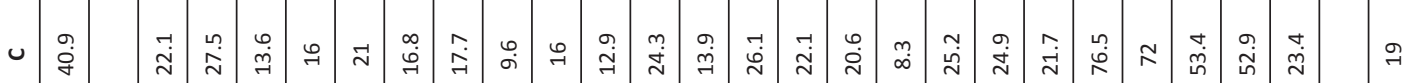

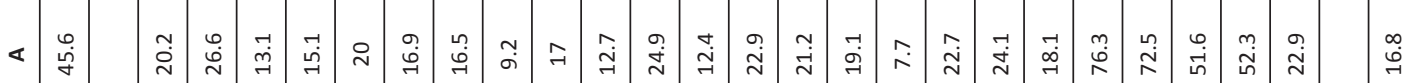

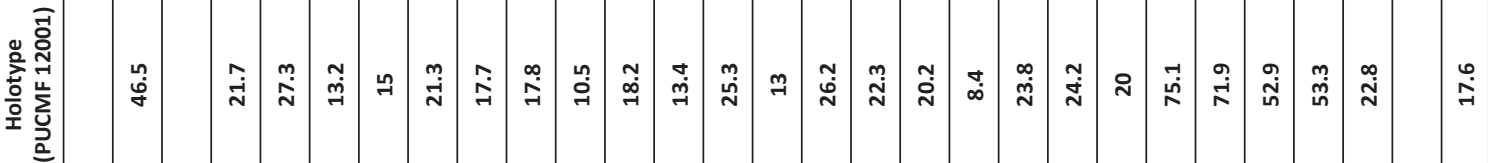

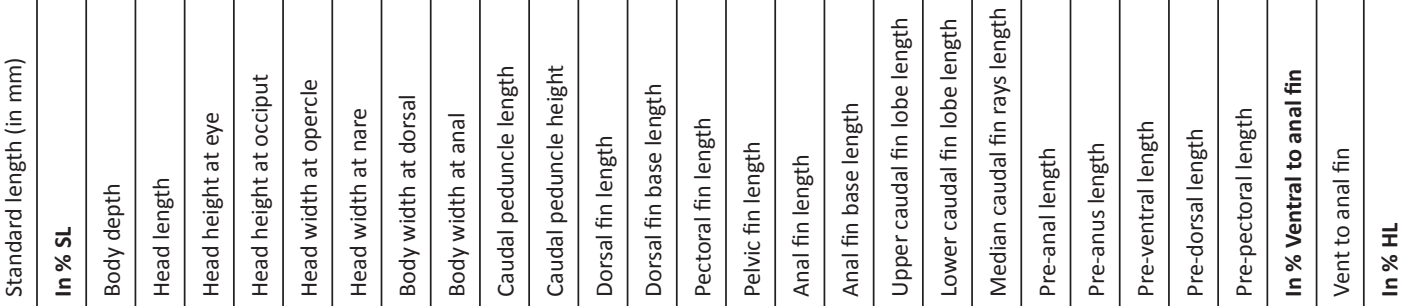




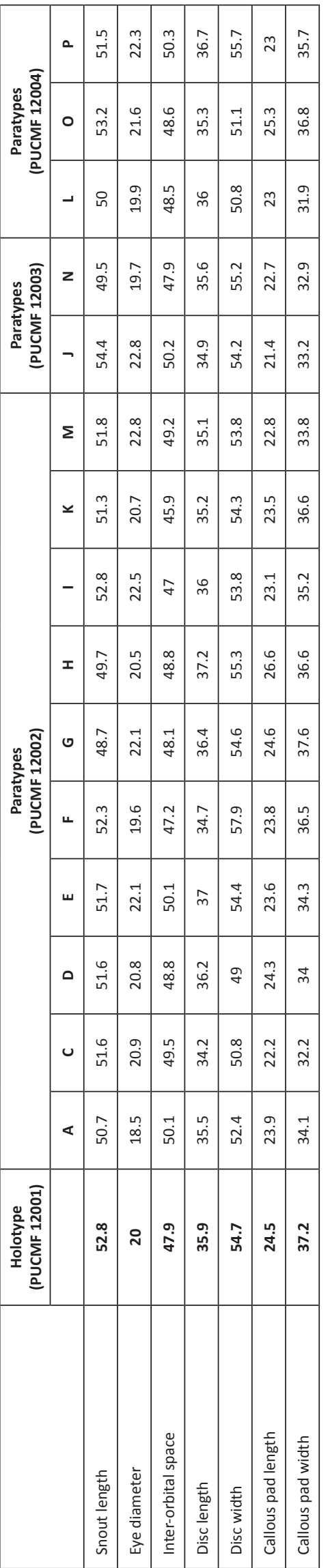

